Proceedings

\title{
Evaluating Land Valuation Techniques and Urban Develop- ment Practices in India
}

\author{
Preeti Jaiswal 1, *, Pooja Nigam ${ }^{2}$ and Satish Pipralia ${ }^{3}$
}

1 Ph.D. Candidate, Department of Architecture and Planning, MNIT Jaipur; ar.preetijaiswal@gmail.com 2 Assistant Professor, Department of Architecture and Planning, MNIT Jaipur; pnigam.arch@mnit.ac.in

3 Associate Professor, Department of Architecture and Planning, MNIT Jaipur; spipralia.arch@mnit.ac.in

* Correspondence: ar.preetijaiswal@gmail.com ; Tel.: +91-9530116585

Citation: Jaiswal, P.; Nigam, P.; Pripalia, S., 2022, Evaluating Land Valuation Techniques and Urban Development Practices in India. SUPTM 2022 conference proceedings sciforum-054456.

https://doi.org/10.31428/10317/10479

Publisher's Note: UPCT and Sciforum stays neutral with regard to jurisdictional claims in published maps and institutional affiliations.

Copyright: (c) 2022 by the authors. Submitted for possible open access publication under the terms and conditions of the Creative Commons Attribution (CC BY) license

(https://creativecommons.org/licen ses/by/4.0/)

\begin{abstract}
The land value of any settlement is a cumulative outcome of the quality of the natural and built environment, which are an amalgamation of many factors. This paper presents the existing state-of-the-art land valuation techniques in urban areas. It discusses the impacts of urban growth parameters, i.e. accessibility, infrastructure, social-economic condition, etc., in detail for sustainable land valuation techniques. The study also developed an Ordinary Least Squares regression equation based on 258 primary sample points from Jaipur, India, to examine the relationship between urban growth parameters and land valuation. This paper is a step toward developing the land valuation models for land value practices.
\end{abstract}

Keywords: Accessibility; Land Use; Land Valuation; Urban Growth; Regression

\section{Introduction}

The people-to-land relationship is dynamic and changes over time in response to cultural, social and economic development. Urban land value is a measure of the land's capacity; it refers to the amount of money for which an asset will exchange in the open market [1,5]. Land market is dynamic and evolves with time along the lines of economic, cultural and social development. Land policies, institutions and systems of land administration are vital tools to govern this relationship [2]. The evolution of land value concerning infrastructure development is explored to understand urban complexities. In a nutshell, urban land value results from resources of economy, environment, livability, and infrastructure development.

\subsection{Evolution of Urban Land Valuation and Development Parameter}

Land value model were first given by Burguss and Park (1925), as Concentric Zone Model, based on monocentric development. According to Hoyt'1939, direction, as well as distance, from the central business district (CBD) is important in determining land use [3]. In 1964, Alanso gave bid rent theory for urban land value; based on microeconomic theory was basically developed in the context of urban land uses. Young and Reilly,1970, described that the interaction between two entities relies on their respective size and mutual distance. Multi-Objective Land-Use Planning Model'1983 states that minor land-use decision can have a significant and lasting effect upon the functional and economic development of a city [4]. Nelson and Frank E. James'1992 finds that the landfills, Ambient Noise levels and Visual Quality affect the value of residential land. Norman G. Miller and David M. Geltner'2005 presented real world cities model which explains that cities are not purely mono-centric; they have other major activity areas besides the CBD. The model mentioned above explains that the value of a land asset is decided by plot location and by various urban development parameters [5]. Literature study says that to model the impact of urban development parameters various statistical techniques were used such as least squares regression, the minimum sum of absolute errors, multiple criteria regression models. The common goal of these studies is to quantify the correlation between property 
values and desirable/undesirable characteristics of the area. This paper explains residen- 1 tial land price dependency on the spatial structure development Practices.

\section{Area of study}

India has one of the world's largest urban systems and is rapidly urbanising. As per Census 2011, India is 31percent urbanised, and studies proved that the urbanisation level shall reach the 50 percent mark by the year 2050. The population concentration in a few major cities is a defining feature of Indian urbanisation. India's most populous top ten cities with their land price assessment are shown in Table-1.

Table 1: Land Price Assessment of Most Populated Cities of India

\begin{tabular}{clcccc}
\hline \multicolumn{7}{c}{ City-wise Prices Assessment of Residential Land } \\
\hline S.No. & \multicolumn{1}{c}{ City } & Population 2011 & Pop. Growth Rate & Av. land Price & Price Range \\
\cline { 3 - 6 } & & & 2019 & (Rs./Sq-ft) on Jan-2020 \\
\hline $\mathbf{1}$ & Mumbai & $12,442,373$ & $1.11 \%$ & 20,496 & $3532-75591$ \\
\hline $\mathbf{2}$ & Delhi & $11,034,555$ & $3.21 \%$ & 21,301 & $5195-54203$ \\
\hline $\mathbf{3}$ & Bangalore & $8,443,675$ & $3.98 \%$ & 6,684 & $953-23291$ \\
\hline $\mathbf{4}$ & Hyderabad & $6,731,790$ & $2.84 \%$ & 2,700 & $230-21323$ \\
\hline $\mathbf{5}$ & Ahmedabad & $5,577,940$ & $2.54 \%$ & 5,895 & $448-12842$ \\
\hline $\mathbf{6}$ & Chennai & $4,646,732$ & $2.54 \%$ & 4,730 & $23766-461$ \\
\hline $\mathbf{7}$ & Kolkata & $4,496,694$ & $0.59 \%$ & 4,663 & $260-13339$ \\
\hline $\mathbf{8}$ & Surat & $4,467,797$ & $4.85 \%$ & 3819 & $204-21050$ \\
\hline $\mathbf{9}$ & Pune & $3,124,458$ & $2.90 \%$ & 6,058 & $317-15512$ \\
\hline $\mathbf{1 0}$ & Jaipur & $3,046,163$ & $2.67 \%$ & 4,761 & $1074-14153$ \\
\hline
\end{tabular}

The price range mentioned in Table-1 shows a disparity in the land price, which may significantly be attributed to infrastructure or urban development. Jaipur city can be taken as the most relevant example to study, as it is India's tenth-biggest city; as per Census 2011 , Jaipur has 30.7 lakh (Here, 1 Lakh $=100000$ ) of the urban population. This urbanisation is attributed to the city's concentration of administrative, job opportunities, trade, and tourism-related economic activity. The land value range of Jaipur is from 1074 to $14153 ₹$ per sq.ft, which reflects uneven development of economic and physical infrastructure within the city. The master plan of Jaipur shows the chronological development of the city. In 1971, a total of 2023.5 hac. land i.e. $50 \%$ of total development, was dedicated to a residential area, which by the end of 2019 increased up to 17445 hac. i.e. $66 \%$ of the total developed space. To understand urban development, growth and sprawl within the city, one can measure the residential land price holistically. Thus to study residential land price, an OLS analysis has been taken up in Jaipur.

\section{Methodology}

A plausible hypothesis has been framed i.e. Urban growth within the Jaipur city can significantly control land value heterogeneity. To forecast more relevant parameters, the DELPHI Technique has been used. This method relies on the key assumption that forecasts from a group are generally more accurate than those from individuals. For situation inventory total 44 experts survey has been done, these surveys have been conducted during Jan'2020 to March'2020. Green (1982) and Vogel \& Wilkins (2019) suggest that at least 70 percent of Delphi subjects need to rate seven or higher on a ten point Likert-type scale [6]. For real time test of these parameters a correlation analysis has been done with land

11 12 13 14 15 16 17 18 19 20 21 22 
value data set. The required data is generated from primary survey, of 250 sample points from Jaipur Municipal Corporation Area (JMC), one sample from each ward. Land value data of selection are taken from the real estate valuer; and the data of recommended development parameters is collected through household surveys and extracted from the GIS-based master plan taken from the Jaipur Development Authority (JDA). Bruce'2009, says the correlation coefficient, denoted by $\mathrm{r}$, is a measure of the strength of the straightline or linear relationship between two variables. To develop model equation OLS regression analysis has been done. Here regression result has R-square or coefficient of determination that tells the percentage variation in $\mathrm{y}$ explained by all the $\mathrm{x}$ variables together. Usually the R square of 0.70 and higher is considered good and explains model is best fit [6].

A data sets of dependent and independent variables were prepared for the OLS regression equation, and the desirable results from this stage will draw conclusions and develop a contextual strategy based on the analysis. Feasibility studies will be conducted to determine the model's technical and social viability.

\section{Results}

The consensus of experts from DELPHI result shows that total 35 infrastructure parameters came from expert survey, for real time test of these parameters a correlation analysis has been done with land price. The correlation results explain that only ten parameters have strong correlation with land value, as they all have correlation coefficient greater than \pm 0.7 , Further to define land price relation with urban growth parameters an OLS regression model is prepared. Here, R-Square is 0.75 , this explains a is strong mutual dependency between the independent and dependent variables; it shows model is the best fit. OLS regression results are shown in Table- 2 and Table- 3 .

Table 2: Model Summary

\begin{tabular}{|c|c|c|c|c|c|c|c|c|c|c|}
\hline \multirow[t]{2}{*}{ Model } & \multirow[t]{2}{*}{$\mathrm{R}$} & \multirow{2}{*}{$\begin{array}{c}\mathrm{R} \\
\text { Square }\end{array}$} & \multirow{2}{*}{$\begin{array}{c}\text { Adjusted R } \\
\text { Square }\end{array}$} & \multirow{2}{*}{$\begin{array}{c}\text { Std. Error } \\
\text { of the } \\
\text { Estimate }\end{array}$} & \multicolumn{5}{|c|}{ Change Statistics } & \multirow[b]{2}{*}{$\begin{array}{l}\text { Durbin- } \\
\text { Watson }\end{array}$} \\
\hline & & & & & $\begin{array}{l}\text { R Square } \\
\text { Change }\end{array}$ & $\begin{array}{c}\mathrm{F} \\
\text { Change }\end{array}$ & df1 & $\mathrm{df} 2$ & $\begin{array}{c}\text { Sig. F } \\
\text { Change }\end{array}$ & \\
\hline 1 & .871 & 0.758 & .751 & 10006.895 & .758 & 107.429 & 9 & 308 & .000 & 1.132 \\
\hline
\end{tabular}

The regression results are analysed to develop the model equation. Here, in Table-3, three variables give a positive influence and six variables give negative influence. This is shown from the estimate value of the parameter coefficients. If the distance is shorter from Railway station, Bus terminus, Mela ground, Commercial proposal and from Fire safety catchment land, than it will give higher land prices. Otherwise, distance from Government hospital, Quality of water, Electricity supply condition, and Economic condition variables can be interpreted that if these services are increases then land value will also increase.

Table 3: Model Analysis Result

\begin{tabular}{lllllll}
\hline & Coefficients & Standard Error & $t$ Stat & P-value & Lower 95\% & Upper 95\% \\
\hline Intercept & $\mathbf{3 6 4 3 6 . 7 8}$ & 12009.30 & -3.03 & 0.00 & -60056.72 & -12816.83 \\
\hline Distance from Railway Station $\left(\mathrm{x}_{1}\right)$ & $\mathbf{- 0 . 5 3}$ & 0.18 & -2.88 & 0.00 & -0.88 & -0.17 \\
\hline Distance from Bus Terminus $\left(\mathrm{x}_{2}\right)$ & $\mathbf{- 0 . 6 9}$ & 0.27 & -2.57 & 0.01 & -1.23 & -0.16 \\
\hline Distance from Mela Ground $\left(\mathrm{x}_{3}\right)$ & $\mathbf{- 0 . 3 7}$ & 0.28 & -1.32 & 0.05 & -0.92 & 0.18 \\
\hline Distance from Govt. Hospital $\left(\mathrm{x}_{4}\right)$ & $\mathbf{0 . 1 2}$ & 0.36 & 0.35 & 0.03 & -0.58 & 0.83 \\
\hline Distance from fire safety catchment land $\left(\mathrm{x}_{5}\right)$ & $\mathbf{- 0 . 0 2}$ & 0.30 & -0.08 & 0.04 & -0.62 & 0.57 \\
\hline Quality of Water (Rate 1-10) $\left(\mathrm{x}_{6}\right)$ & $\mathbf{1 0 4 0 8 . 1 5}$ & 1013.38 & 10.27 & 0.00 & 8415.03 & 12401.28 \\
\hline Electricity supply condition $\left(\mathrm{x}_{7}\right)$ & $\mathbf{2 4 1 1 . 9 1}$ & 875.49 & 2.75 & 0.01 & 690.00 & 4133.82 \\
\hline
\end{tabular}




\begin{tabular}{lllllll}
\hline Economic condition $\left(\mathrm{x}_{8}\right)$ & $\mathbf{- 5 6 7 6 . 2 8}$ & 626.04 & -9.07 & 0.00 & -6907.58 & -4444.98 \\
\hline Distance from commercial Proposal $\left(\mathrm{x}_{9}\right)$ & $\mathbf{- 0 . 3 9}$ & 0.29 & -1.34 & 0.18 & -0.95 & 0.18 \\
\hline
\end{tabular}

The result indicates that all variables affect the land value significantly. As the sig. value (p-value) is less than 0.05 for confidence level $95 \%$. Here, coefficients tell the intercept value, and gives the coefficients value of an independent variable. From Table-3 data, the model equation for market land value is as follow.

\section{Land Value Model Equation \\ Land Value $=36436-\left(0.53^{*} x_{1}\right)-\left(0.69^{*} x_{2}\right)-\left(37^{*} x_{3}\right)+\left(0.12^{*} x_{4}\right)-\left(0.02^{*} x_{5}\right)+\left(10408^{*} x_{6}\right)+$ $\left(2411.91^{*} x_{7}\right)-\left(5675^{*} x_{8}\right)-\left(0.39^{*} x_{9}\right)$}

The model equation considers urban development factors and it quantifies the individual share of them. The given analysis also suggests that the city's residential land value resilience is linked with the city's economic development; as 75 percent of residential land price is explained by the given parameters. So if any planning, and development body, is proposing dwelling unit development, they should consider this model for inclusive and sustainable spatial development. This research explains that land prices can determine the development of infrastructure within a city.

\section{Conclusions}

The results of the study can be summarized as first, there is a significant relationship between infrastructure development and land price growth in Indian cities, and secondly, the heterogeneity of infrastructure development is captured through the land value distribution. The result also explains the contribution of Economic condition, Quality of water, Electricity supply condition and the Distance from railway station, Bus Terminus, Mela Ground, commercial Proposal, Government hospital and from Fire safety catchment land is 75 percent and rest 25 percent is hedonistic, this may depend on other parameters of literature analysis. It infers that the policies with aim to encourage new development in cities can consider of these infrastructure too for inclusive, resilient and sustainable development. It also explains that a linear regression model can predict the urban land value and obtain the future growth map. GIS-based Statistical models are advantageous in predicting complex urban systems of urban growth, land suitability, and supply of infrastructure with the vision for forthcoming demand in the Indian context.

Funding: This research received no external funding.

Acknowledgments: I would like to express my gratitude to the Jaipur Development Authority's staff and Town Planning Department of Rajasthan for providing required data.

Conflicts of Interest: The authors declare no conflict of interest.

\section{References}

1. Mancia, A., Droj, G., \& Droj, L. (2010). Nominal assets valuation by GIS. GIS OPEN 2010 (pp. 1-6). Magyarországi Egyetem: University of Oradea.

2. $\quad$ Enemark, S., Hvingel, L., \& Galland, D. (2014). Land administration, planning and human rights. Planning Theory, 13(4), 331348. https://doi.org/10.1177/1473095213517882

3. Ai, Ping. (2005). Residential land value modelling Residential land value modelling [International Institute for Geo-Information Science and Earth Observation Enschede, The Netherlands]. https://webapps.itc.utwente.nl/librarywww/papers_2005/msc/upla/ai_ping.pdf

4. Vedia F., D6kmecU, Giilen; Selma, T. (1993). Multiobjective Land-Use Planning Model. Journal of Urban Planning and Development, 119(1), 15-22. https://doi.org/https://doi.org/10.1061/(ASCE)0733-9488(1993)119:1(15)

5. Jaiswal, P., Nigam, P., \& Pipralia, S. (2019). Factors affecting Urban Land Valuation and Practices in India. In P. C. Anderson (Ed.), 7th Annual International Conference on Architecture and Civil Engineering (ACE 2019) (pp. 190-195). Singapore: Global Science and Technology Forum (GSTF). https://doi.org/10.5176/2301-394X_ACE19.173

6. McAuliffe, R. E. (2015). Wiley Encyclopedia of Management. Wiley. doi:10.1002/9781118785317.weom080200 